\title{
Residual stress analysis by different bias voltage of DLC films on AISI 4050 alloy steel
}

\section{Análise da tensão residual em filmes de DLC sobre a liga de aço AISI 4050 por variação da tensão aplicada}

Joao Thiago de Guimaraes Anchieta e Araujo Campos ${ }^{1}$, Vagner Eduardo Caetano Marques², Erica Almeida ${ }^{1}$

Evaldo José Corat² ${ }^{2}$ Danilo Maciel Barquete ${ }^{1}$

\begin{abstract}
Thin films are one the best choice to improve materials properties. Instead of entire replacement of the material in a component, which may be expensive, a coating process is a good option to achieve required properties precisely where they are required. Generally, coating depends on deposition methods which consist of chemical or physical interactions to form a film on substrate surface. Residual internal stresses are generated during cooling stage after deposition process, due to always present difference in thermal expansion coefficient of film and substrate materials. These stresses produce either failure or performance reduction on component utilization. Raman spectroscopy was used to evaluate these residual stresses. In this work Raman spectrum behavior was analyzed under different residual stress conditions of DLC films deposited on a 4050 steel/molybdenum alloy steel substrates. The comparative method used at three different bias tensions of $-550,-650$ and $-750 \mathrm{~V}$ showed that residual stress increases with increasing bias voltage. The normal compressive load to produce delamination in scratching test decreased from $16 \mathrm{~N}$ to $9 \mathrm{~N}$ with bias voltage increase from $-550 \mathrm{~V}$ to $-750 \mathrm{~V}$, as expected due to higher interface stresses.
\end{abstract}

Keywords: Residual stress; Bias voltage; DLC film.

\section{RESUMO}

Filmes finos são ótimas escolhas para a melhoria das propriedades de materiais. Ao invés da substituição de um material em um componente onde pode gerar um alto custo, o processo de revestimento é uma boa opção para adquirir as propriedades necessárias. Geralmente, o revestimento depende de métodos de deposição que consiste em interações químicas ou físicas para formar um filme sobre o substrato. A tensão residual ocorre geralmente durante o processo de resfriamento após a deposição devido a diferença de coeficientes de expansão entre os materiais entre o filme e o substrato. Além de causar falhas no material, a tensão residual pode reduzir consideravelmente as propriedades do componente em que ocorre a deposição. Nesse trabalho a espectropia Raman foi utilizada para avaliar as propriedades de um filme, especificamente a tensão residual entre o filme e uma liga 4050 de aço/molibdênio. Foi avaliado a tensão residual considerando três diferentes tensões de deposição, tais que -550v, - 650v e -750v. A análise mostrou que a tensão residual aumenta quando há aumento da tensão aplicada para deposição. A carga normal de compressão para delaminação foi reduzida de $16 \mathrm{~N}$ para $9 \mathrm{~N}$ quando há aumento da tensão aplicada, resultado esperado devido ao aumento das tensões residuais entre o filme e o substrato.

Palavras-chave: Tensão residual; Tensão de crescimento; Filme de DLC

\footnotetext{
'Universidade Estadual de Santa Cruz - Ilhéus (BA) - Brazil

Instituto Nacional de Pesquisas Espaciais - São José dos Campos (SP) - Brazil

Correspondence author: Joao Thiago Campos - UESC - Campus Soane Nazaré de Andrade (Salobrinho), Km 16 - BR 415 - CEP $45662-900$ Ilhéus (BA) - Brazil

E-mail: joaothiagocampos@gmail.com

Received: 12/12/2013 Approved: 06/11/2015
} 


\section{INTRODUCTION}

Generally, the properties of a thin film are measured by the analysis of its surface. For example, chemical reactions begin on surface and proceed into the bulk, like adsorption, corrosion, passivation, weathering, electrode polarization, etc. Mechanical properties also affect the material initially from the surface, like friction, adhesion, wear, lubrication and bonding ${ }^{(1)}$. Thin films are generally produced from carbon containing materials and deposited and fixed on another material, the substrate. The study of thin films depends not only on its composition, but also on substrate properties. Among thin films, diamond and diamondlike carbon are materials with a large set of properties of interest to many applications of high technology. The main difference of diamond and diamond-like carbon is the proportion of $\mathrm{sp}^{2}$ and $\mathrm{sp}^{3}$ bounds in the film. Diamond has only $\mathrm{sp}^{3}$ bounds with a structure derived from face-centered cubic; diamond-like carbon varies $\mathrm{sp}^{2}$ and $\mathrm{sp}^{3}$ bounds ratio on a planar trigonal structure. A high concentration of $\mathrm{sp}^{2}$ bounds characterizes graphite with planar structure $^{(2)}$. Furthermore, diamond films may have others elements than carbon, like hydrogen which changes strongly material properties. For example, the Young's modulus of a diamond-like carbon with $5 \%$ of hydrogen is almost $900 \mathrm{GPa}$ and less than 300 GPa for a DLC film with more than $20 \%$ of hydrogen ${ }^{(3)}$. This huge variation depends not only on hydrogen amount but on the relation of $\mathrm{sp}^{2}$ and $\mathrm{sp}^{3}$ bounds. Extreme wear resistance and low friction coefficient make diamond-like carbon an important coating option for high performance and high technology products. Its use in high technology applications is wide and constantly growing, replacing polymers, ceramics and metals with better mechanical and chemical responses. However, DLC films deposition process affects substrate mechanical properties, mainly due to residual stresses in the interface DLC-substrate. These stresses are due to the different thermal contraction between coating and substrate during cooling process after DLC film deposition, resulting in residual stresses in the coatingsubstrate interface. These stresses may causes defects on material or reduction in its mechanical resistance. To improve diamondlike coatings properties it is necessary to develop experimental methods or theoretical models to minimize these residual stresses. Using a suitable method to characterize residual stresses it is possible to evaluate how they affect the materials and their properties, as the residual stresses intensity. While experimental methods permit to identify the behavior of a material based on its properties, mathematical models are important to compare and to understand which variables are affecting these results. This way, the combined use of experimental and theoretical model is important to study residual stress and improve DLC films application. Since residual stress is energy confined in the structure, it is important to use methods for measuring intermolecular behavior as molecular vibrations $^{(4)}$. Raman spectroscopy characterization method was used due its nondestructive and high sensitivity aspects. DLC films quality and residual stress are evaluated by peak shift, type, line width and shape of Raman spectrum ${ }^{(5)}$. DLC films residual stresses are evaluated by peak shift $\Delta \omega_{j}$ from $\omega_{j 0}$ - wavenumber at unstressed condition - to $\omega_{j}$ - wavenumber at stressed condition. The residual stress in a Raman spectrum is proportional to the variation of wavenumber by the Equation 1:

$\sigma=\Delta \omega_{j}=\omega_{j}-\omega_{j 0}$

Many authors use the equation deduced for crystalline silicon [100] under biaxial stress to calculate the residual stresses ${ }^{(6)}$ :

$\sigma(\mathrm{MPa})=-250 . \Delta \omega\left(\mathrm{cm}^{-1}\right)$

where

$\sigma=\frac{\sigma_{\mathrm{xx}}+\sigma_{\mathrm{yy}}}{2}$

Using Eq. 2 and the condition of no polarization settings for incident scattered light, an average value can be obtained ${ }^{(6)}$.

The equation may be used for any set of film/ substrate materials. Although the equation was derived for stressed crystalline silicon, the stress factor $\mathrm{k}$ changes for each crystalline material and orientation $^{(5)}$, which results in a new general Eq. 4:

$\sigma(\mathrm{MPa})=\mathrm{k} \cdot \Delta \omega\left(\mathrm{cm}^{-1}\right)$

In this paper we analyze the behavior of residual stresses on DLC film deposited on steel alloy doped with molybdenum substrate by different bias voltage using Raman spectroscopy and a theoretical model.

\section{METHOD}

The method used on this study is a comparative analysis of residual stress in DLC films deposited on AISI 4050 alloy steel, at different bias voltages. This method is divided in three steps:

- DLC film growth process

DLC films were grown on AISI 4050 alloy steel substrates in a PECVD reactor, at three different bias voltages of $-550 \mathrm{~V},-650 \mathrm{~V}$ and $-750 \mathrm{~V}$. Each deposition process was performed at the following conditions: duration of $90 \mathrm{~min}$, pressure of $1.5 \times 10^{-1} \mathrm{Torr}$ and constant $3 \mathrm{sccm}$ gas flow. Silicon plasma at $1.5 \times 10^{-1}$ Torr pressure was applied during the initial 20 minutes of process to enhance film/ substrate adherence.

The substrate is a 4050 steel alloy with $0.5 \%$ wt carbon and $0.3 \%$ wt molybdenum. Molybdenum alloy steels have excellent strength, good mechanical stability at high temperature, ductility and toughness. The interest on this substrate in this study is due to its good tribological properties, especially friction resistance. 


\section{- Raman characterization}

The Raman spectrum analysis was used to identify wavenumber shifts to calculate residual stress in the DLC films. It was used a micro-Raman system, model RENISHAW 2000 with wavelength visible excitation of $514.5 \mathrm{~nm}$ using argon laser, calibrated with a natural crystalline diamond with peak at $1332 \mathrm{~cm}^{-1}$.

\section{- Tribometer characterization:}

Friction resistance evolves many parameters about DLC film and substrate. Residual stresses added to friction forces decrease surface wear resistance of DLC film and substrate system. If the film is under high residual stresses, it may delaminates (release from substrate) during friction loads. With the tribometer test it is possible to analyze the load necessary to delaminate the film and the change of this load for different DLC coatings. Loads up to $20 \mathrm{~N}$ were applied to the film, starting from $0 \mathrm{~N}$ and gradually increasing until the film is released from substrate. A tribometer, model UMT2-CETR, assess the adherence from the DLC film to the substrate, in atmospheric environment.

\section{- Residual stress analysis}

Residual stresses are calculated and analyzed as a dependent variable of tension generated during growth process. Comparing the different loads to delaminate the film from substrate and the wave number shift, it is possible to make quantitative and qualitative analysis of residual stress behavior.

\section{DISCUSSION AND RESULTS}

In the PECVD process for DLC deposition the a-C:H (amorphous carbon structure) film has been deposited with three different bias voltages of $-550 \mathrm{~V},-650 \mathrm{~V}$ and $-750 \mathrm{~V}$. DLC films were then characterized by comparing the amorphous level of $\mathrm{D}$ and $\mathrm{G}$ peaks ratio:

The low IP/IG ratio shows high sp3 bounds on the DLC structure. The intensity has been measured by two Gaussians curves fitted and a linear background (as shown in Figs. 1 to 3). By increasing bias voltages, the D and $\mathrm{G}$ band ratio increases characterizing more amorphous structure.

The Raman spectrum peaks shifts shown on Figs. 1 to 3 are due to residual stresses on DLC film. By changing bias voltage it is possible to analyze the influence of the tension applied on residual stresses. Table 2 shows peak shifts compared to bias voltage applied. The peak shifts due to variations from $-550 \mathrm{~V}$ to $-650 \mathrm{~V}$ and $-650 \mathrm{~V}$ to $-750 \mathrm{~V}$ indicate the behavior of bias voltage change in residual stresses.

Table 1: Raman analysis of DLC coating

\begin{tabular}{|c|c|c|c|}
\hline Bias $(\mathrm{V})$ & $\mathrm{D}$ band $\left(\mathrm{cm}^{-1}\right)$ & $\mathrm{G}$ band $\left(\mathrm{cm}^{-1}\right)$ & $\mathrm{I}_{\mathrm{P}} / \mathrm{I}_{\mathrm{G}}$ \\
\hline-550 & 1301.49 & 1531.75 & 0.267 \\
\hline-650 & 1307.67 & 1536.69 & 0.293 \\
\hline-750 & 1303.03 & 1541.02 & 0.311 \\
\hline
\end{tabular}

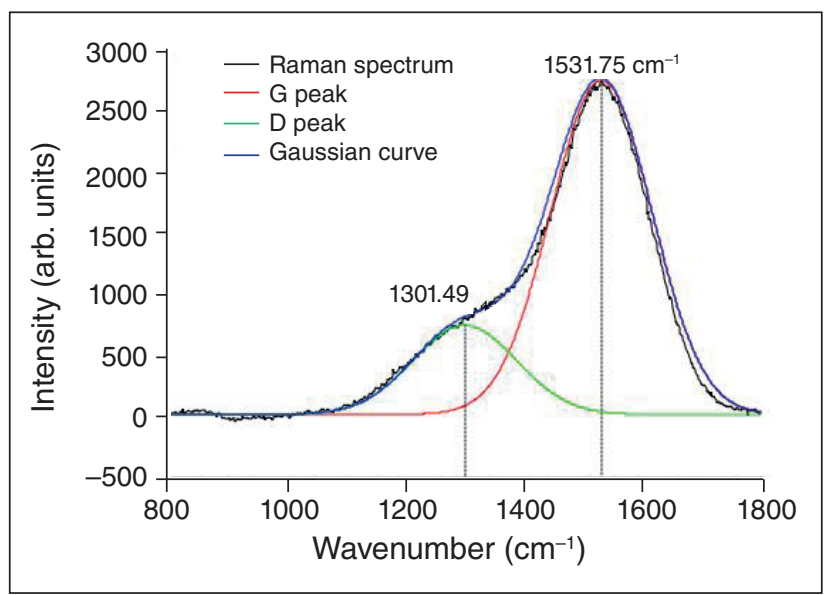

Figure 1: $D$ and $G$ curves of a $D L C$ film deposited at $-550 \mathrm{~V}$ bias voltage.

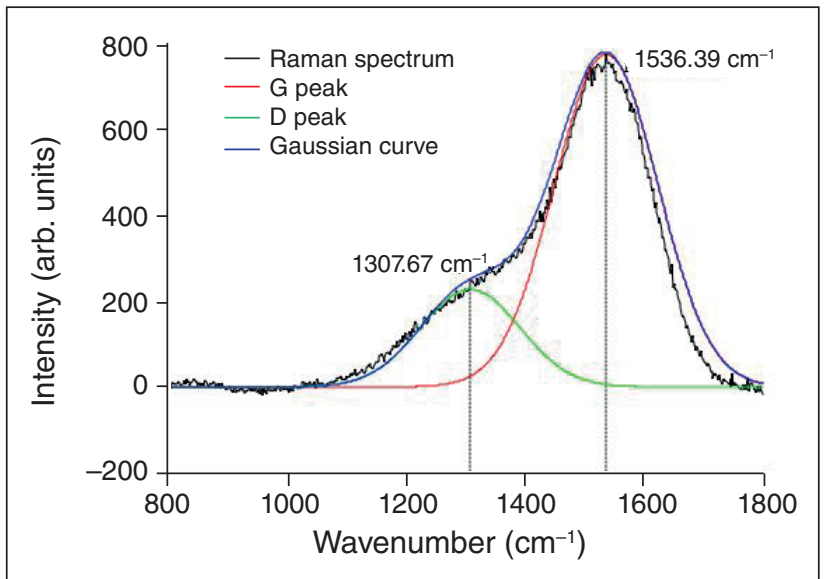

Figure 2: $D$ and $G$ curves of a DLC film deposited at $-650 \mathrm{~V}$ bias voltage.

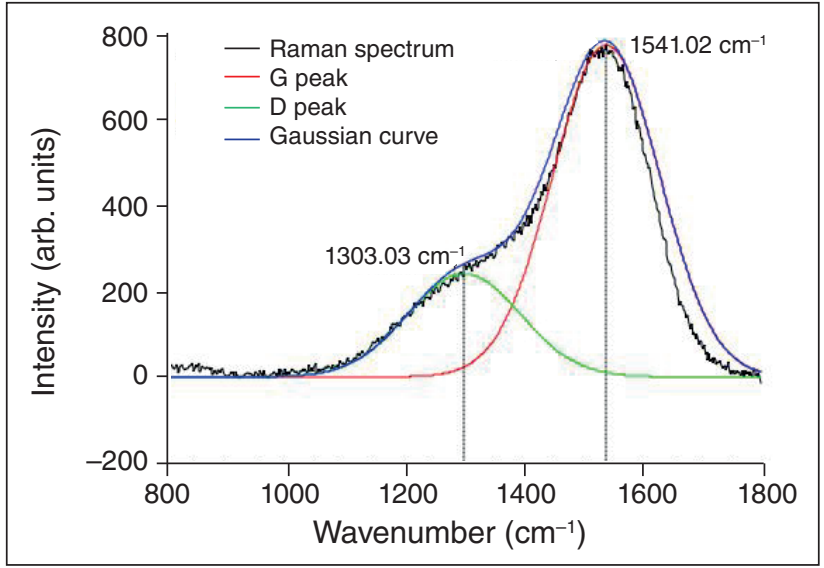

Figure 3: $\mathrm{D}$ and $\mathrm{G}$ curves of a DLC film deposited at $-550 \mathrm{~V}$ bias voltage.

Table 2: Measured data of DLC Raman peak shifts by different bias (V)

\begin{tabular}{c|c|c|c|c|c|c|}
\hline & \multicolumn{4}{|c|}{ Characteristic peak of diamond-like carbon } \\
\cline { 2 - 8 } & \multicolumn{3}{|c|}{ D peak } & \multicolumn{3}{c|}{ G peak } \\
\cline { 2 - 8 } & $\begin{array}{c}\mathbf{1}^{\text {st }} \text { peak } \\
\left(\mathbf{c m}^{-1}\right)\end{array}$ & $\begin{array}{c}\mathbf{2}^{\text {nd }} \text { peak } \\
\left(\mathbf{c m}^{-1}\right)\end{array}$ & $\Delta \omega$ & $\begin{array}{c}\mathbf{1}^{\text {st }} \text { peak } \\
\left(\mathbf{c m}^{-1}\right)\end{array}$ & $\begin{array}{c}\mathbf{2}^{\text {nd }} \text { peak } \\
\left(\mathbf{c m}^{-1}\right)\end{array}$ & $\Delta \omega$ \\
\hline $\begin{array}{c}-550 \mathrm{~V} \text { and } \\
-650 \mathrm{~V}\end{array}$ & 1301.49 & 1307.67 & 6.18 & 1531.75 & 1536.39 & 4.64 \\
\hline $\begin{array}{c}-650 \mathrm{~V} \text { and } \\
-750 \mathrm{~V}\end{array}$ & 1307.67 & 1303.03 & -4.64 & 1536.39 & 1541.02 & 4.63 \\
\hline
\end{tabular}




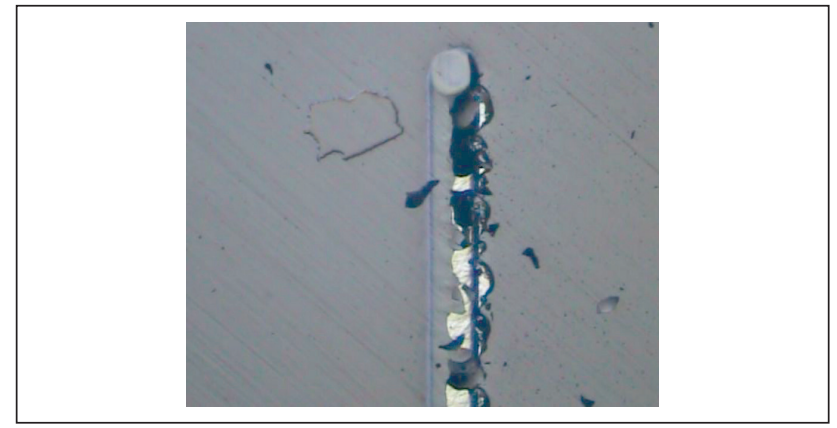

Figure 8: Optical microscopy image of $10 \mathrm{~N}$ load scratch on DLC film deposited at $-750 \mathrm{~V}$ bias. DLC film has delaminated from substrate.

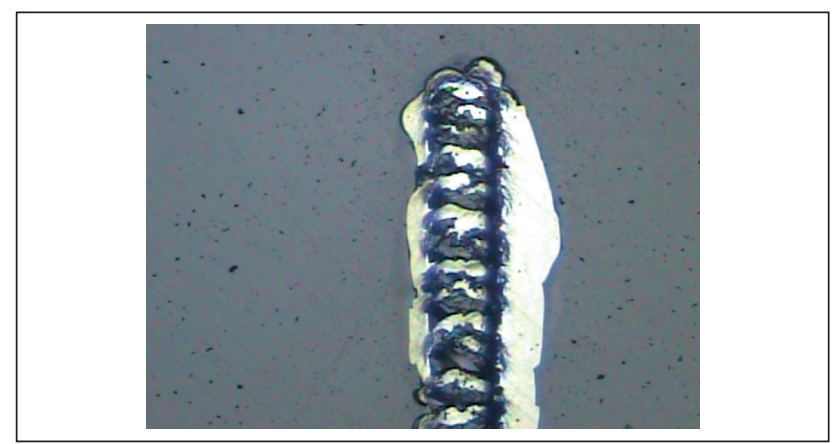

Figure 9: Optical microscopy image of $15 \mathrm{~N}$ load scratch on DLC film deposited at $-750 \mathrm{~V}$ bias. DLC film is removed from substrate.

\section{CONCLUSION}

Residual stress occurs on every thin film deposited on substrates above ambient temperatures. Due to different thermal expansion coefficient of materials, these stresses arises during the cooling process from deposition temperature. Controlling the variables of deposition process it is possible to control this energy confined in film and the DLC film adhesion to the substrate. The AISI 4050 molybdenum alloy steel was an adequate choice as substrate, due to the good adherence and friction resistance of the deposited
DLC. This study evaluates the behavior of residual stress by controlling the bias voltage applied in the plasma-enhanced chemical vapor deposition method (PECVD). The Raman spectrum has shown higher residual stresses for films with higher bias voltages applied. At the different bias voltages applied the DLC films has kept the same crystalline structure, evaluated by the D and G band ratio, meaning that the film adherence to the substrate changed due to residual stresses in the film. Residual stress in the DLC films can be adjusted by controlling PECVD process variables, as bias voltage applied, to improve film adherence to substrate, without changing crystalline structure of the film.

\section{ACKNOWLEDGEMENTS}

The authors would like to thank CAPES for its financial support.

\section{REFERENCES}

1. RADOVIC, L.R.; RODRIGUEZ-REINOSO, F., Carbon materials in catalysis. In: Thrower PA, editor. Chemistry and physics of carbon, vol 25, New York; Dekker; 1975 p. 243-358.

2. DRESSELHAUS, M. S.; DRESSELHAUS, G.; SAITO R., Physics of carbon nanotubes. Carbon 1995; 33(7): p. 883-91.

3. BROWN, D.K.; GARNER, C.E.; MUELLER, J., Unidirectional carbon/carbon for ion engine optics. Extended abstracts, 22nd biennial conf. on carbon. UC San Diego (California. USA): American Carbon Society, 1995; p. 152-3.

4. PIERSON, H. O., Handbook of carbon, diamond and fullerenes. Park Ridge NJ: Noyes. 1993: p. 87-94.

5. GHOSH, D.; SUBHASH, G.; ORLOVSKAYA, N., Measurement of scratch-induced residual stress within $\mathrm{SiC}$ grains in $\mathrm{ZrB}_{2}-\mathrm{SiC}$ composite using micron-Raman spectroscopy. Acta Materialia, 2008; 56: p. 5345-5354.

6. KANG, Y.; QIU, Y.; LEI, Z. et al., An aplication of Raman spectroscopy on the measurement of residual stress in porous silicon. Optics and Lasers in Engineering, 2005. 43: p. 847-855. 